\title{
MASAŽO IR KINEZITERAPIJOS POVEIKIS SKAUSMUI IR EDEMAI PO MENISKO OPERACIJOS
}

\author{
Kristina Venckūnienė, Ričardas Būrè, Vida Ostasevičienè \\ Lietuvos sporto universitetas
}

\section{SANTRAUKA}

Tyrimo pagrindimas. Nepaisant vis didejjančio susirūpinimo, koks geriausias reabilitacijos protokolas būtų tinkamas atsižvelgiant ị menisko operacijos pobūdị, skausmo ir edemos mažinimas yra pagrindiniai uždaviniai pirmuoju reabilitacijos laikotarpiu po menisko operacijos. Teorija rodo, kad atidèliojant skausmo ir edemos šalinimą gali padidèti antriniai sužalojimai, ir atsigavimas po operacijos bus ilgesnis. Masažas kaip viena iš saugių ir nefarmokologinių priemonių dažnai naudojamas skausmui ir edemai mažinti.

Tikslas - įvertinti masažo, taikomo kartu su kineziterapijos užsièmimais, poveikị ligonių po kelio sąnario menisko operacijos skausmui ir edemai.

Metodai. Buvo tirta 14 asmenų po menisko operacijos. Tiriamieji atsitiktiniu būdu suskirstyti i dvi grupes. Tiriamajai grupei buvo taikoma kineziterapinè mankšta ir klasikinis gydomasis masažas, kontrolinei - kinezitarpija. Prieš tyrimą ir po jo buvo vertinamas skausmo intensyvumas (VAS skale), judesio ar pasikartojančios traumos baimè (Tampa kineziofobijos skale), išmatuotos abiejų kelių apimtys.

Rezultatai. Po reabilitacijos procedūrų kelio skausmas, edema ir judesio ar pasikartojančios traumos baimès rodiklis reikšmingai sumažèjo abiejose grupėse $(\mathrm{p}<0,05)$. Ligonių, kuriems buvo taikytas masažas ir kineziterapija, skausmo intensyvumas, edema ir judesio ar pasikartojančios traumos baimès rodiklis statistiškai reikšmingai sumažejo labiau nei atlikusių tik kineziterapijos pratimus $(\mathrm{p}<0,05)$.

Išvados. Masažas, atliekamas kartu su kineziterapijos pratimais, efektyviau sumažino asmenų po menisko operacijos skausmą, edemą ir judesio ar pasikartojančios traumos baimę nei tik kineziterapijos pratimai.

Raktažodžiai: menisko operacija, edema, skausmas, klasikinis masažas.

\section{IVADAS}

Menisko plyšimai yra dažna kelio sąnario trauma, įvykstanti šešiems iš 1000 populiacijoje, nuo dviejų su puse iki keturių kartų dažniau vyrams nei moterims (Shiraev et al., 2012). Plyšimai įvyksta dèl šlyties jègos tarp šlaunikaulio ir blauzdikaulio, kai atliekant judesị viršutinė kūno dalis sukasi ị priešingą pusę nei žemiau kelio sąnario esanti kojos dalis. Jaunesniojo amžiaus tarpsniu dažniausiai tai įvyksta sportinès veiklos metu, pagyvenusiems žmonėms - dèl degeneracinių kelio sąnario pakitimų.

Dabartinès galimos menisko gydymo galimybès yra neoperacinis gydymas, meniskektomija, susiuvimas ir transplantacija. Pastaruoju metu, jei pažeidimas gydomas operuojant, kelio sąnario meniską stengiamasi išsaugoti. Tyrimais įrodyta, kad menisko išsaugojimas sumažina osteoartrito vystymąsi, o lyginant su dali- 
niu menisko pašalinimu rezultatai ir ligonių būklè būna geresnè (Petty, Lubowitz, 2011). Japonijoje, atlikus 2007-2014 m. duomenų analizę, pastebèta, kad sparčiai padidèjo žmonių, kuriems atliktas menisko susiuvimas, ir smarkiai sumažèjo tų, kuriems atlikta meniskektomija, ypač jaunesniems. Meniskektomija dažniausiai buvo atliekama senyvo amžiaus žmonėms, o meniskai susiuvami paaugliams (Kawata et al., 2018). Dèl šių priežasčių norima išsiaiškinti, kokia yra optimali technika operuojant ir kokia pati geriausia pooperacinio laikotarpio reabilitacija. Protokolai varijuoja nuo „pagreitintų“, kuomet gan greit po operacijos leidžiama lenkimo per kelio sąnarị judesio amplitudè yra 90 ir daugiau laipsnių, o jègos pratimai leidžiami iki ligonio toleravimo, kiti - kai judesio amplitudè yra ribojama, o jègos pratimai - ne, ir atvirkščiai - tiek judesio, mažesnio nei $\leq 90$ laipsnių, tiek jègos pratimų ribojimo. Taip pat yra nustatomas progresijos dažnis, laikas, kada galima grįžti ị sportinę veiklą. Visgi, kaip parodè sisteminè analizė, ankstyva judesių amplitude ir jègos pratimai nebuvo pranašesni nei kiti reabilitacijos būdai (O'Donnell et al., 2017). Kaip teigia mokslininkai, reabilitacijos strategijos turi būti susietos su menisko plyšimo tipu ir kitais biologiniais veiksniais.

Skausmas, kelio sąnario patinimas, sumažejusi judesių amplitude, blauzdos lenkiamųų ir tiesiamujų raumenų jèga yra būdingi simptomai po kelio sąnario operacijos. Edemos valdymas po traumos ar sužalojimo yra pagrindinis sveikatos priežiūros specialistų rūpestis, nes teorija rodo, kad atidèliojant edemos pašalinimą padidès antriniai sužalojimai ir atsigavimo rezultatas bus ilgesnis (Majewski-Schrage, Snyder, 2016). Judejimą po operacijos gali riboti ir baimė patirti skausmą, pakartotinai susižaloti. Kineziofobija apibūdinama kaip perdèta, neracionali ir sekinanti fizinio judejjimo ir aktyvumo baimè, atsirandanti dèl pažeidžiamumo ir jautrumo skausmingiems ar pakartotiniams sužalojimams (Kori et al., 1990). Nepaisant fizinio pajėgumo pagėejjimo po reabilitacijos, yra nemažai asmenų, kurie, patyrę priekinių kryžminių raiščiu operaciją, negrižta ị prieštrauminị lygị. Ypač fiziškai aktyvūs, iš kurių tik $63 \%$ grịžta i pilnai atgautą potrauminị lygị. Tai gali būti dèl nuolatinio kelio skausmo, patinimo, sustingimo ir silpnumo, taip pat ir kineziofobijos (Cozzi et al., 2015).

Masažas, kaip vienas iš saugių ir nefarmakologinių priemonių, dažnai yra naudojamas skausmo ir edemų mažinimui, raumenų tonuso ir jẻgos didinimui, audinių mitybos gerinimui (Field et al., 2005; Weerapong et al., 2005; Sefton et al., 2012). C. Waters-Banker ir kt. (2014), analizuodami masažo poveikio mechanizmus, iliustruoja, kokiu greičiu periferinè nervų sistema gali tapti „efektyvi“ perduodant skausmą, ir rodo, kaip svarbu laiku moduliuoti ankstyvą imunini atsaką. Ji teigia, kad masažas suaktyvina naudingus imunomoduliacinius mechanizmus, kurie mažina skausmą. B. F. Miller'io ir kt. (2018) tyrimo rezultatai rodo, kad masažas kaip 
ciklinio kompresinio krūvio forma pajëgus padidinti raumens masès atsigavimą po neveiklumo sukeltos atrofijos laikotarpio, ir tai ịvyksta dèl to, kad padideja mechaniškai pakeista signalinè transdukcija, baltymų sintezė ir raumens rekonstravimas. Autoriai implikuoja, kad masažas kaip terapinè manipuliacija, kuri dažniausiai gerai toleruojama, gali būti pradedamas gana greitai, kai baltymų praradimas yra didžiausias ir turi galimybę smarkiai paveikti klinikinius rodiklius tų asmenų, kurie guli lovoje ar jiems neleidžiama perkelti svorio ant pažeistos kojos po traumos ar chirurginès intervencijos. Todèl manome, kad ankstyvas masažas galètų pagreitinti funkcijos atsigavimą po kelio sąnario menisko operacijos.

Tyrimo tikslas - įvertinti masažo, taikomo kartu su kineziterapijos pratimais, poveikị ligonių po kelio sąnario menisko operacijos skausmui, edemai.

\section{METODAI}

Tiriamieji. Buvo tiriama 14 ligonių (10 vyrų ir 4 moterys), atvykusių į reabilitacijos įstaigą vidutiniškai po 3-7 dienų po artroskopinès kelio menisko operacijos. I tyrimą buvo ịtraukti vienpusio pažeidimo asmenys po pirminès meniskų operacijos, be komplikacijų operaciniu laikotarpiu. Tiriamieji atsitiktine tvarka buvo suskirstyti ị dvi grupes: kontrolinę ( 5 vyrai ir 2 moterys) ir tiriamają (5 vyrai ir 2 moterys). Kontrolinès grupès tiriamuju amžiaus vidurkis $-34,29 \pm 2,5$ m., kairiojo ir dešiniojo menisko pažeidimu pasiskirstymas - 86 ir 14\% atitinkamai. Tiriamosios grupès amžiaus vidurkis $-33,00 \pm 2,2 \mathrm{~m}$., kairiojo ir dešiniojo menisko pažeidimų pasiskirstymas $-71 \%$ ir $29 \%$ atitinkamai. Tiriamieji buvo supažindinti su atliekamu tyrimu, gautas raštiškas jų sutikimas.

Tyrimo organizavimas. Tiriamieji buvo vertinami du kartus - prieš tyrimą ir po jo. Tiriamajai grupei buvo taikyti kineziterapijos pratimai saleje ir klasikinis gydomasis masažas, kontrolinei - kineziterapijos pratimai saleje. Taip pat visiems ligoniams buvo taikytos fizioterapijos procedūros.

Klasikinio gydomojo masažo procedūra, susidedanti iš glostymo, trynimo, maigymo ir vibracijos, buvo atliekama tiriamosios grupès asmenų kojai, kuri buvo operuota. Tiriamiesiems buvo atlikta 10 procedūrų, masažo procedūros trukmé 20 minučių.

Kineziterapijos pratimus salèje atliko abiejų grupių tiriamieji kiekvieną dieną, 6 kartus per savaitę, 1 kartą per dieną po 30 minučių, iš viso 10 mankštų. Kineziterapijos pratimų programa individualizuota, atsižvelgiant ị ligonio funkcinę būklę, remiantis pratimų vykdymo nuoseklumo ir laipsniškumo principais. 


\section{Tyrimo metodai}

Vizualioji analogu skale (VAS). Suvokiamas skausmo intensyvumas buvo vertinamas prieš masažą ir po jo naudojant Vizualiają skaitmeninę analogų skalę. Skalejje pavaizduota linija, ant kurios sužymèti skaičiai nuo vieno iki dešimt, kur nulis reiškia, kad skausmo nėra, o skaičius dešimt rodo nepakeliamą skausmą Ši skalė yra pripažinta Lietuvos sveikatos apsaugos ministerijos (LR SAM ịsakymas Nr.V608).

Tampa kineziofobijos skale. Judesio ar pasikartojančios traumos baimė buvo ivertinta Tampa kineziofobijos skale. Klausimyną sudaro 17 su skausmu ir ligonio būkle susijusių teiginių, į kuriuos pateikiami atsakymai ir jų vertinimas balais. Kuo daugiau balų tiriamasis surenka, tuo labiau jo judejimą riboja baimè patirti skausmą ar pakartotinai susižeisti.

Abiejų keliu apimčiu vertinimas. Kelių apimčių vertinimas atliekamas norit nustatyti operuoto kelio patinimo laipsni. Kelio apimtis vertinama matuojant operuotajj ir sveikaji kelius centimetrine juostele. Matavimas atliekamas per kelio sąnario vidurị.

Matematinė statistika. Tyrimo duomenų analizei atlikti naudojome „Microsoft Excel 2010“ ir „IBM SPSS Statistics 22“ programas. Apskaičiuoti gautu rezultatu vidurkiai, standartiniai nuokrypiai. Ranginiai (VAS skausmo ir Tampa kineziofobijos skalès) duomenys pateikti mediana. Dviejų nepriklausomų grupių kiekybiniams dydžiams palyginti buvo taikomas Mann'o-Whitney'aus U testas. Kiekybiniams priklausomiems kintamiesiems palyginti buvo taikomas Wilcoxon'o testas. Skirtumai tarp grupių buvo laikomi statistiškai reikšmingi, kai $\mathrm{p}<0,05$.

\section{TYRIMO REZULTATAI}

Vizualiosios analogų skalès duomenys parodè, kad po reabilitacijos procedūru kelio skausmas reikšmingai sumažèjo abiejose grupėse $(\mathrm{p}<0,05)(1 \mathrm{pav}$.). Tiriamujų, kuriems buvo taikytas masažas ir kineziterapija, skausmo intensyvumas statistiškai reikšmingai sumažèjo labiau nei atlikusiujų tik kineziterapiją $(\mathrm{p}<0,05)$.

Prieš reabilitaciją abiejų grupių operuoto kelio apimties skirtumai, lyginant su sveikają koja, buvo panašūs ( $p>0,05)$. Po tyrimo kelio tinimas sumažejo abiejose grupèse, tačiau tiriamosios grupès asmenims, kuriems buvo taikytas masažas ir kineziterapija, kelio apimtis sumažèjo labiau nei tụ, kuriems buvo taikyta tik kineziterapija $(\mathrm{p}<0,05)$. 


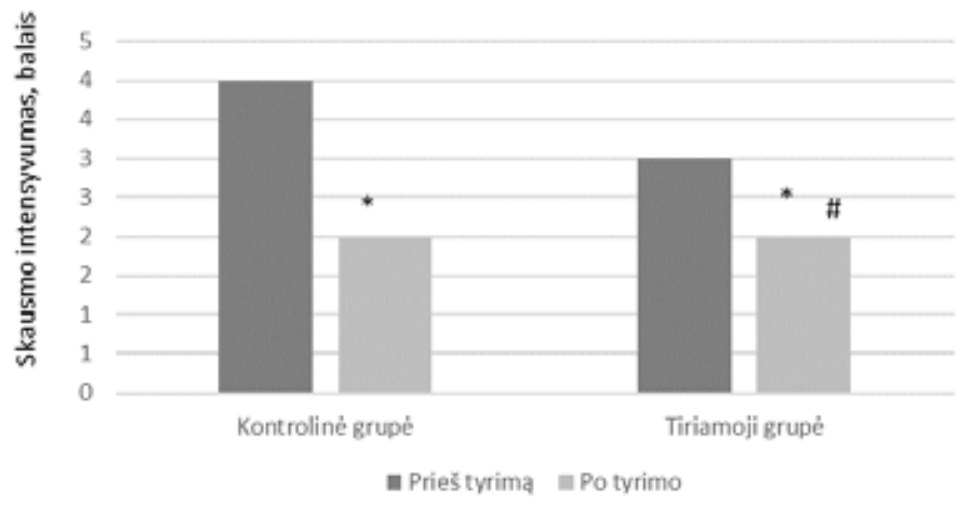

Pastaba. $*_{-} \mathrm{p}<0,05$, lyginant abi grupes prieš tyrimą ir po jo; \# - lyginant kontrolinès ir tiriamosios grupès rodiklius po tyrimo.

1 pav. Abiejų grupių tiriamųjų skausmo intensyvumas prieš tyrimą ir po jo

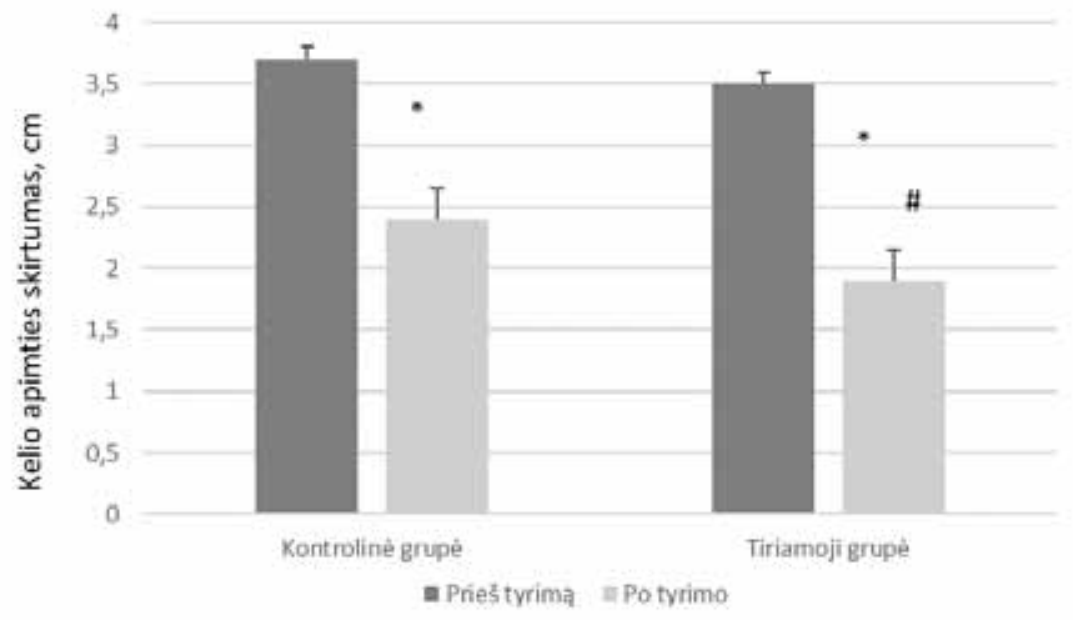

Pastaba. $*_{-}$p $<0,05$, lyginant abi grupes prieš tyrimą ir po jo; \# - lyginant kontrolinès ir tiriamosios grupès rodiklius po tyrimo.

2 pav. Abiejų grupių tiriamųjų kelio apimčių, lyginant su sveikąja koja, rodiklių skirtumas prieš tyrimą ir po jo 


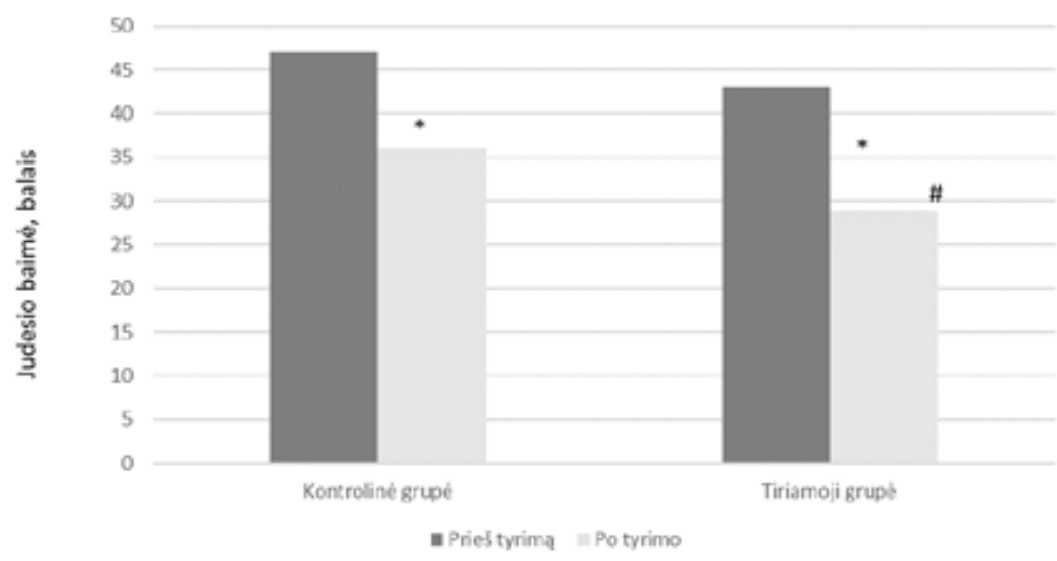

Pastaba. ${ }^{*}-\mathrm{p}<0,05$, lyginant abi grupes prieš tyrimą ir po jo;

\# - lyginant kontrolinès ir tiriamosios grupès rodiklius po tyrimo.

\section{3 pav. Abiejų grupių tiriamųjų judesio ar pasikartojančios traumos baimès pokytis prieš tyrimą ir po jo}

Prieš reabilitaciją abiejų grupių judesio ar pasikartojančios traumos baimės rodiklis buvo panašus $(p>0,05)$. Po reabilitacijos sumažějo abiejų grupių ligonių baimè $(\mathrm{p}<0,05)$ ir statistiškai reikšmingai labiau sumažèjo tų, kuriems buvo taikytas masažas ir kineziterapija $(\mathrm{p}<0,05)$.

\section{REZULTATŲ APTARIMAS}

Meniskų pažeidimus ir jų chirurginę gydymo priemonę patiria ịvairaus amžiaus žmonès nuo 17 iki 60 metų amžiaus. Dažniau šią traumą patiria vyrai nei moterys, o kairysis kelio sąnarys pažeidžiamas dažniau nei dešinysis (Esmaili Jah et al., 2005). Atliktas tyrimas patvirtina šią tendenciją - tirtų asmenų kairiojo ir dešiniojo meniskų pažeidimai buvo pasiskirstę atitinkamai 78,6 ir 21,4\%.

Mūsų tyrimo tikslas buvo įvertinti masažo poveikị asmenų po menisko operacijos skausmui. Nustatyta, kad masažas, taikomas kartu su kineziterapijos procedūromis, labiau sumažino asmenų po menisko operacijos skausmą ir edemą nei tik kineziterapijos procedūros. Tyrime, kurị atliko P. C. Goodwin ir kt. (2003), pirmuoju reabilitacijos laikotarpiu buvo taikyta ultragarso terapija, ledas ir gilus frikcinis masažas bei sąnario mobilizacija. Frikcinis rando masažas buvo atliekamas 5 minutes pirmają reabilitacijos dieną ir tęsiamas kitomis dienomis tol, kol nebebuvo apčiuopiama jokių audinių apribojimų. Kai skausmas ir tinimas sumažèjo, pereita prie kito reabilitacijos laikotarpio ir pratimai buvo taikomi tuo atveju, 
kai skausmas pagal VAS skalę nebuvo didesnis nei 3 iš dešimties. S. M. Kim'as ir kt. (2015) įrodè, kad mechaninis masažas po pilnos kelio artroplastikos sumažino skausmą ir edemą. Skausmas sumažejo nuo $3,5 \pm 0,5$ iki $2,1 \pm 0,8$ balo po 20 minučių šlaunies paviršinio limfodrenažinio masažo, atliekamo penkias dienas iš eilès. Susiformavus edemai, limfinè sistema vaidina pagrindinị vaidmenị pašalinant perteklinị tarpląstelinị skystị ir grąžinant skysčius ị kraujotakos sistemą (Majewski-Schrage, Snyder, 2016). J. R. Ebert'as ir kt. (2013) pastebejjo, kad atlikus kelio sąnario artroskopiją akivaizdžiai padidejo kelio sąnario lankstumas po gydymo manualiniu limfodrenažiniu masažu, palyginti su ịprastiniu gydymu. Mūsų tyrimo rezultatai parodè, kad kelio tinimas sumažèjo ir masažas reikšmingai sumažino edemą. Nors klasikinio gydomojo masažo būdai skiriasi nuo limfodrenažinio, masažo kryptys ir spaudimo jèga yra tos pačios, link artimiausių limfmazgių.

Mūsų tyrimo rezultatai parodè, kad judesio ar pasikartojančios traumos baimé po reabilitacijos sumažèjo vidutiniškai 12,5 balo ir labiau sumažějo tos grupès, kuriai buvo taikytas masažas. A. Tichonova ir kt. (2016) nustatè, kad tiriamujų, patyrusių meniskektomiją, judesio ar pasikartojančios traumos baimès (TSK-11) rodikliai prieš reabilitaciją buvo 23,1 balo, po reabilitacijos $-18,7$ balo, tačiau reikia pabrěžti, kad reabilitacija buvo taikyta praejjus 28 dienoms po chirurginès intevencijos, ir autoriai naudojo trumpesnę Tampa kineziofobijos skalès versiją.

Nepaisant to, kad dauguma tyrimų analizuoja, kokị reabilitacijos protokolą geriausia parinkti asmenims po meniskų operacijos, atsižvelgiama tik į judesių amplitudę ir operuotos kojos apkrovą. Visgi manome, kad tikslinga taikyti ankstyvajj klasikini gydomąị masažą. Tai būtų tinkama strategija ligonio skausmui, edemai mažinti, o tuo pačiu slopinant baimę judèti ir patirti traumą.

\section{IŠVADOS}

Masažas, atliekamas kartu su kineziterapijos pratimais, sumažino asmenų po menisko operacijos skausmą, edemą ir judesio ar pasikartojančios traumos baimę labiau nei tik kineziterapijos užsièmimai.

\section{LITERATŪRA}

Cozzi, A. L., Dunn, K. L., Harding, J. L., Valovich McLeod, T. C., Welch Bacon, C. E. (2015). Kinesiophobia after anterior cruciate ligament reconstruction in physically active individuals. Journal of Sport Rehabilitation, 24 (4), 434-439.

Ebert, J. R., Joss, B., Jardine, B., Wood, D. J. (2013). Randomized trial investigating the efficacy of manual lymphatic drainage to improve early outcome after total knee arthroplasty. Archives of Physical Medicine and Rehabilitation, 94, 2103-2111.

Esmaili Jah, A. A., Keyhani, S., Zarei, R., Moghaddam, A. K. (2005). Accuracy of MRI in comparison with clinical and arthroscopic findings in ligamentous and meniscal injuries of the knee. Acta Orthopaedica Belgica, 71 (2),189-196. 
Field, T., Hernandez-Reif, M., Diego, M., Schanberg, S., Kuhn, C. (2005). Cortisol decreases and serotonin and dopamine increase following massage therapy. International Journal of Neuroscience, 115 (10), 1397-1413.

Goodwin, P. C., Morrissey, M. C., Omar, R. Z. et al. (2003). Effectiveness of supervised physical therapy in the early period after arthroscopic partial meniscectomy. Physical Therapy, 83 (6), 520-535.

Kawata, M., Sasabuchi, Y., Taketomi, S. et al. (2018). Annual trends in arthroscopic meniscus surgery: Analysis of a national database in Japan. PloS One, 13 (4), e0194854.

Kim, S. M., Kim, S. R., Lee, Y. K., Kim, B. R., Han, E. Y. (2015). The effect of mechanical massage on early outcome after total knee arthroplasty: a pilot study. Journal of Physical Therapy Science, 27 (11), 3413-3416.

Kori, S. H., Miller, R. P., Todd, D. D. (1990). Kinesiophobia: A new view of chronic pain behavior. Pain Management, 3, 35-43.

Majewski-Schrage, T., Snyder, K. (2016). The Effectiveness of manual lymphatic drainage in patients with orthopaedic injuries. Journal of Sport Rehabilitation, 25 (1), 91-97.

Miller, B. F., Hamilton, K. L., Majeed, Z. R. et al. (2018). Enhanced skeletal muscle regrowth and remodelling in massaged and contralateral non-massaged hindlimb. The Journal of Physiology, 596 (1), 83-103.

O’Donnell, K., Freedman, K. B., Tjoumakaris, F. P. (2017). Rehabilitation protocols after isolated meniscal repair: A systematic review. The American Journal of Sports Medicine, 45 (7), 1687-1697.

Petty, C. A., Lubowitz, J. H. (2011). Does arthroscopic partial meniscectomy result in knee osteoarthritis? A systematic review with a minimum of 8 years' follow-up. Arthroscopy, 27 (3), 419-424.

Sefton, J. M., Yarar, C., Berry, J. W. (2012). Six weeks of massage therapy produces changes in balance, neurological and cardiovascular measures in older persons. The International Journal of Therapeutic Massage \& Bodywork, 5 (3), 28-40.

Shiraev, T., Anderson, S. E., Hope, N. (2012). Meniscal tear-presentation, diagnosis and management. Australian Family Physician, 41 (4), 182-187.

Tichonova, A., Rimdeikienè, I., Petruševičienė, D., Lendraitienė, E. (2016). The relationship between pain catastrophizing, kinesiophobia and subjective knee function during rehabilitation following anterior cruciate ligament reconstruction and meniscectomy: A pilot study. Medicina (Kaunas), 52 (4), 229-237.

Waters-Banker, C., Dupont-Versteegden, E. E., Kitzman, P. H., Butterfield, T. A. (2014). Investigating the mechanisms of massage efficacy: The role of mechanical immunomodulation. Journal of Athletic Training, 49 (2,) 266-273.

Weerapong, P., Hume, P. A., Kolt, G. S. (2005). The mechanisms of massage and effects on performance, muscle recovery and injury prevention. Review. Sports Medicine, 35 (3), 235-256.

\title{
EFFECTS OF MASSAGE AND PHYSIOTHERAPY ON PAIN AND OEDEMA AFTER MENISCUS SURGERY
}

\author{
Kristina Venckūnienė, Ričardas Būrè, Vida Ostasevičienė \\ Lithuanian Sports University
}

\begin{abstract}
Background. Despite growing concerns about what best rehabilitation protocol would be appropriate given the nature of meniscus surgery, reducing pain and oedema are key challenges in the first period of rehabilitation after meniscus surgery. The theory suggests that delaying the removal of pain and oedema can lead to increased secondary injuries and a longer recovery from surgery. Massage as one of the safest and non-pharmacological tools is often used to reduce pain and oedema.
\end{abstract}


The aim of this study was to evaluate the effect of massage on the pain and oedema in combination with physiotherapy sessions in patients after knee meniscus surgery.

Methods. This study included 14 persons after meniscus surgery randomly assigned into two groups. The experimental group underwent physiotherapy exercise and classical therapeutic massage, the control group underwent physiotherapy. The intensity of pain (VAS scale), fear of movement or re-injury (Tampa kinesiophobia scale) and both knee volumes were measured before and after the study.

Results. After rehabilitation, knee pain, oedema, and fear of movement or repetitive trauma were significantly reduced in both groups $(\mathrm{p}<0.05)$. Patients undergoing massage and physiotherapy had a statistically significant reduction in pain intensity, oedema, and fear of movement or re-injury compared to patients undergoing physiotherapy alone $(\mathrm{p}<0.05)$.

Conclusion. Massage combined with physiotherapy sessions was more effective in reducing pain, oedema, and fear of movement or repetitive trauma in individuals after meniscus surgery than physiotherapy sessions alone.

Keywords: meniscus surgery, pain, oedema, massage.

Gautas 20190624

Priimtas 20191111 